\title{
STUDIES ON THE CHEMICAL DIAGNOSIS OF PELLAGRA (NICOTINIC ACID DEFICIENCY) ${ }^{1}$
}

\author{
By HENRY FIELD, JR., DANIEL MELNICK, ${ }^{2}$ WILLIAM D. ROBINSON, ${ }^{3}$ aND \\ CHARLES F. WILKINSON, JR.4 \\ (From the Department of Internal Medicine, Medical School, University of Michigan, \\ Ann Arbor)
}

(Received for publication March 31, 1941)

Since the demonstration that nicotinamide is the pellagra-preventing factor (1), attempts have been made to analyze this substance in blood and urine as a measure of nicotinic acid nutrition. Chemical methods and biological methods, to be considered subsequently, have been used. The chemical methods have been based, most commonly, upon the development of colored products by the reaction of various pyridine compounds with cyanogen bromide and aromatic amines, as described by König (2).

This reaction is not specific for nicotinic acid. Other pyridine compounds may give similar colored products. Elvehjem (3) has found that, in the analysis of animal tissues, the reaction as we have applied it gave results quite comparable to those which he obtained by animal assay. He found that, in vegetable materials, the chemical method gave too high values, presumably due to other pyridine compounds. Consequently, blood analyses might be expected to avoid the possible errors due to the concentration of those other compounds in the urine.

Nicotinic acid does not occur, as such, in appreciable quantities in the blood or urine except shortly after the taking of large doses of it $(4,5)$. In the blood, it occurs chiefly in the corpuscles as a constituent of coenzymes I and II.

Nicotinic acid in the blood has been determined by four different procedures: chemical estimation using the cyanogen bromide and aromatic amine reagents, measurement of coenzymes I and II as the essential growth factor for $H$. influenzae or $H$. parainfluenzae, estimation of total nicotinamide

1 The expense of this investigation was defrayed by grants from the Upjohn Company, Kalamazoo, and from the Horace H. Rackham School of Graduate Studies, University of Michigan, Ann Arbor.

2 Upjohn Fellow in Clinical Research, 1937-1940.

3 Upjohn Fellow in Clinical Research, 1938-1940.

4 Upjohn Fellow in Clinical Research, 1940. (both free and in the coenzymes) as the growth factor for $B$. proteus, and measurement of coenzyme I by a specific fermentation method. The results obtained with both normal and deficient subjects are listed in Table I.

TABLE I

Reported values for nicotinic acid content of the blood of human subjects

\begin{tabular}{|c|c|c|c|}
\hline \multirow{2}{*}{$\begin{array}{c}\text { Author } \\
\text { (Reference) }\end{array}$} & \multirow{2}{*}{ Method } & \multicolumn{2}{|c|}{ Whole blood values* } \\
\hline & & Normal & Deficient \\
\hline $\begin{array}{l}\text { Vilter, Koch and } \\
\text { Spies (6) }\end{array}$ & $\begin{array}{l}\text { Measurement of nicotinamide con- } \\
\text { taining coensymes I and II by growth } \\
\text { of } H \text {. influenzac. }\end{array}$ & $\begin{array}{c}0.27-0.87 \\
(43)\end{array}$ & $\begin{array}{l}0.12-0.54 \\
(45)\end{array}$ \\
\hline Lwoff \& al. $(7,8)$ & $\begin{array}{l}\text { Measurement of total nicotinamide } \\
\text { as the growth factor for } B \text {. proteus. }\end{array}$ & $\begin{array}{c}0.62-0.89 \\
(9)\end{array}$ & $\begin{array}{c}0.73-1.03 \\
(10)\end{array}$ \\
\hline $\begin{array}{l}\text { Kohn, Bernheim } \\
\text { and Felsoranyi ( }(\theta)\end{array}$ & $\begin{array}{l}\text { Measurement of coensymes I and II } \\
\text { as growth factor for } H \text {. parainfluenzae. }\end{array}$ & $\begin{array}{l}0.32-0.8 \dagger \\
(53)\end{array}$ & $\begin{array}{c}0.4-0.64 \dagger \\
(9)\end{array}$ \\
\hline $\begin{array}{l}\text { von Euler and } \\
\text { Sohlenk (10) }\end{array}$ & $\begin{array}{l}\text { Measurement of coensyme I by yeast } \\
\text { fermentation method. }\end{array}$ & $\begin{array}{l}\text { Av. } 0.80 \dagger \\
\text { (?) }\end{array}$ & \\
\hline $\begin{array}{l}\text { Axelrod, Gordon } \\
\text { and Elvehjem (11, } \\
\text { 12) }\end{array}$ & Same & $\begin{array}{c}0.33-0.72 \dagger \\
(17)\end{array}$ & $\underset{(1)}{0.63 \dagger}$ \\
\hline Swaminathan (13) & $\begin{array}{l}\text { Chemical determination of total nico- } \\
\text { tinio acid. }\end{array}$ & $\begin{array}{c}0.33-0.53 \\
(3)\end{array}$ & \\
\hline Ritsert (14) & Same & $\begin{array}{c}0.33-0.46 \\
(?)\end{array}$ & \\
\hline Kuihnau (15) & Same & $\begin{array}{c}0.25-0.45 \\
(?)\end{array}$ & $\underset{(4)}{0.08-0.18}$ \\
\hline Villela (16) & Same & $0.25-0.64$ & \\
\hline
\end{tabular}

* The figure in parentheses represents the number of subjects in that study.

$\dagger$ These values were originally given as the coenzyme concentration. The nicotinic acid content of coenzymes I and II is considered to be $\mathbf{1 7 . 4}$ per cent of the molecules (average value) and 18.5 per cent of coenzyme I alone. Whenever originally expressed in terms of corpuscular volume, values were converted to whole blood values by assuming an hematocrit of 43 per cent. All of the coenzymes are in the corpuscles (17) but the hematocrits of patients may have been low.

Most of the workers did not find a significant difference in the nicotinic acid content of the blood of normal and deficient subjects. In the large series of Vilter, Kock and Spies (6), consisting of 43 normal and 45 deficient subjects which showed the most impressive differences, there were 12 in- 
stances of overlapping of values for whole blood in the two groups. There were many more instances of overlapping of values between the two groups when they were expressed in terms of the coenzyme content of the blood cells, as was done by Kohn, Bernheim, and Felsoranyi (9), because the coenzymes had been shown to be confined to the corpuscles (17).

Significant decreases in the coenzyme content of the blood of deficient subjects were not found by the other workers who used biological methods. Lwoff and associates $(7,8)$ measured the growthpromoting effect for $B$. proteus, while Kohn and Bernheim (9) measured that for a strain of $H$. parainfluenzae. When the growth of an organism is used to measure a vitamin, it is necessary to eliminate the effect of all other growth-promoting factors, as was shown by Sinclair (18) in using the growth of Phycomyces blakesleeanus as a measure of thiamine. Vilters, Koch and Spies (6) note that parallel studies using both $H$. influenzae and $H$. parainfluenzae have not always given comparable results.

The figures obtained by chemical tests on human blood were lower than those obtained by biological methods and there were few such observations on the blood of deficient subjects. In the chemical methods used, there were possibilities of loss of nicotinic acid by inadequate extraction or by adsorption on charcoal or on precipitated protein. Protein precipitants have been shown to precipitate the nicotinamide-containing coenzymes of the blood $(19,20)$. Benzene extraction (15, $16)$ is unreliable because of the very limited solubility of nicotinic acid in this solvent (21).

Pearson (22), using a chemical method, reported the finding of a low blood nicotinic acid in one dog with blacktongue. This was not confirmed by the more extensive studies of blacktongue by Kohn, Klein and Dann (23) or by Axelrod, Madden, and Elvehjem (24), using biological methods. It has been a consistent finding $(23,24,25,26)$ that, in blacktongue, there are considerable decreases in the nicotinic acid (or coenzyme) content of some tissues, notably liver and muscle.

In urine, nicotinic acid occurs as its amide, as nicotinuric acid, the glycine conjugate, and as trigonelline, the methylated form. The chemical relationship between these compounds is indicated by the structural formulae presented in Figure 1 . Free nicotinic acid and nicotinuric acid are not present in the urine in significant amounts either normally or after dosage with nicotinamide (5, 27). They both occur in the urine after large doses of nicotinic acid $(5,27)$. Nicotinamide and nicotinuric acid react directly with the cyanogen bromide and aromatic amine reagents, the intensity of the color produced being dependent upon the choice of the latter. Only after acid or alkaline hydrolyses (preferably acid hydrolysis, to which trigonelline is resistant) of proper normality and duration can theoretical values be obtained for them (28).

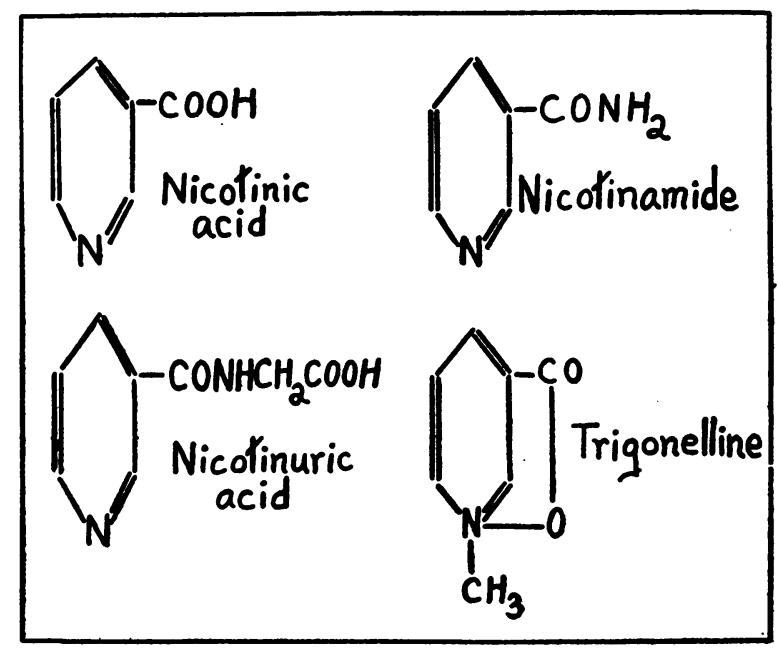

Fig. 1. Structural Formulae of Nicotinic Actd and Its Derivatives

The greater portion of nicotinic acid is excreted as trigonelline (27). This does not react with the reagents to produce a color. It is susceptible to alkaline hydrolysis which permits at least partial, semiquantitative recovery $(28,29)$. There may be, however, large amounts of trigonelline in urine from other sources than methylation of nicotinic acid. It is widely distributed among foods (30, 31 ), with no quantitative data available except that coffee is a rich source (32). It, or a compound with similar hydrolytic behavior, also occurs from detoxification of nicotine and possibly of other pyridine compounds (28). (A fraction of nicotine, the size of the fraction varying in different individuals, is also excreted in a form which is determined in the " nicotinic acid" fraction of urine.) Since trigonelline possesses no 
TABLE II

Studies of the excretion of "nicotinic acid" in urine from human subjects

\begin{tabular}{|c|c|c|c|c|c|c|c|c|c|}
\hline \multirow{3}{*}{$\begin{array}{c}\text { Author } \\
\text { (Reference) }\end{array}$} & \multirow{3}{*}{$\begin{array}{l}\text { Hydrolytio } \\
\text { procedure }\end{array}$} & \multirow{3}{*}{ Decolorisation } & \multirow{3}{*}{ Blank test } & \multirow{3}{*}{$\begin{array}{l}\text { Reagents for } \\
\text { ohemical reaction }\end{array}$} & \multirow{2}{*}{\multicolumn{2}{|c|}{$\frac{\begin{array}{c}\text { Urinary " nicotinic } \\
\text { acid" values" }\end{array}}{\text { Basal }}$}} & \multicolumn{3}{|c|}{ Urinary "nicotinio acid" values" } \\
\hline & & & & & & & \multicolumn{3}{|c|}{ After oral test dose $\nmid$} \\
\hline & & & & & Normal & Deficient & Dose & Normal & Deficient \\
\hline $\begin{array}{l}\text { Vilter, Spies and } \\
\text { Mathews (5) }\end{array}$ & None & Charcoal & $\begin{array}{l}\text { On reagents } \\
\text { alone }\end{array}$ & $\begin{array}{l}2,4 \text { dinitrochloro- } \\
\text { bensene and sodium } \\
\text { hydroxide }\end{array}$ & $\begin{array}{l}\text { mom. per } \\
\text { (?) } \\
20-50\end{array}$ & $\begin{array}{c}24 \text { hours } \\
\text { (3) } \\
0\end{array}$ & mom. & mgm. per firat & hours \\
\hline Bandier (34) & $\underset{\substack{\text { hour } \\
\text { 1.2 }}}{\mathrm{NaOH}}$ & $\begin{array}{l}\text { Acetone ex- } \\
\text { traction after } \\
\text { salting out }\end{array}$ & $\begin{array}{l}\text { Test solution } \\
\text { plus cyanogen } \\
\text { bromide }\end{array}$ & $\begin{array}{l}\text { Cyanogen bromide } \\
\text { and metol }\end{array}$ & $\stackrel{(10)}{1.5-5.0}$ & & $80 t$ & (1) 12.5 & \\
\hline Swaminathan (35) & $\begin{array}{l}2 \underset{3}{\mathrm{~N}} \mathrm{NaOH} \\
\mathrm{Nours}\end{array}$ & Charcoal & $\begin{array}{l}\text { Test solution } \\
\text { plus aniline }\end{array}$ & $\begin{array}{l}\text { Cyanogen bromide } \\
\text { and aniline }\end{array}$ & $\begin{array}{c}(26) \\
0.6-8.9\end{array}$ & $\begin{array}{c}(8) \\
0.9-2.2\end{array}$ & 100 & (26) $1.1-29.6$ & (8) $1.0-12.7$ \\
\hline Riteert (14) & $\begin{array}{l}2.5 \mathrm{~N} \mathrm{HCl} \\
2 \text { hours }\end{array}$ & $\begin{array}{l}\text { Benzene ex- } \\
\text { traction after } \\
\text { dehydration }\end{array}$ & $\begin{array}{l}\text { On reagents } \\
\text { alone }\end{array}$ & $\begin{array}{l}\text { Cyanogen bromide } \\
\text { and aniline }\end{array}$ & $0.8-4.58$ & & & & \\
\hline $\begin{array}{l}\text { Harris and } \\
\text { Raymond (36) }\end{array}$ & $\begin{array}{c}0.8 \mathrm{~N} \mathrm{NaOH} \\
\mathrm{N} \text { hour }\end{array}$ & None & $\begin{array}{l}\text { Test solution } \\
\text { plus p-amino- } \\
\text { acetophenone }\end{array}$ & $\begin{array}{l}\text { Cyanogen bromide } \\
\text { and p-amino- } \\
\text { acetophenone }\end{array}$ & $\stackrel{(6)}{3.1-7.3}$ & $\stackrel{(2)}{1.8-2.9}$ & & & \\
\hline Porjé (37) & None & None & $\begin{array}{l}\text { On test solu- } \\
\text { tion alone }\end{array}$ & $\begin{array}{l}\text { Cyanogen bromide } \\
\text { and aniline }\end{array}$ & $1.2-20.0$ & $\begin{array}{l}(1) \\
0\end{array}$ & 50 & $\stackrel{\text { (?) }}{\text { Approximately } 4}$ & (1) \\
\hline Kühnau (15) & $\begin{array}{l}2.5 \mathrm{~N} \mathrm{HCl} \\
2 \text { hours }\end{array}$ & $\begin{array}{l}\text { Bensene ex- } \\
\text { traction after } \\
\text { dehydration }\end{array}$ & $\begin{array}{l}\text { On reagents } \\
\text { alone }\end{array}$ & $\begin{array}{l}\text { Cyanogen bromide } \\
\text { and aniline }\end{array}$ & $\stackrel{(?)}{0.8-4.58}$ & $\stackrel{(4)}{1.0-1.68}$ & $100-500$ & (?) $0-4$ & (2) $0-4$ \\
\hline $\begin{array}{l}\text { Rosenblum and } \\
\text { Jolliffe (38) }\end{array}$ & $\begin{array}{c}0.08 \mathrm{M} \\
\mathrm{KH}_{2} \mathrm{PO}_{4} \\
5 \text { minutes }\end{array}$ & None & $\begin{array}{l}\text { Test solution } \\
\text { plus oysanogen } \\
\text { bromide }\end{array}$ & $\begin{array}{l}\text { Cyanogen bromide } \\
\text { and metol }\end{array}$ & $\stackrel{(13)}{3.4-10.2}$ & $\begin{array}{l}(1) \\
0-2.8\end{array}$ & 100 & & (1) 1 \\
\hline
\end{tabular}

* The figure in parentheses represents the number of subjects used in each of the studies.

$\dagger$ These values have been corrected for the basal excretions prior to the administration of the test dose.

$\ddagger$ Test dose of nicotinic acid taken while fasting.

$\$$ These values, given originally by the authors as micrograms per cent, were obtained by assuming an average 24hour urine volume of $1500 \mathrm{cc}$.

|| In these tests nicotinamide constituted the test dose.

anti-blacktongue activity (33), provision must be made to avoid the obscuration of results by the excretion of trigonelline arising from non-vitamin sources.

In Table II are summarized the analyses of urines from both normal and pellagrous subjects reported from other laboratories. In order to evaluate the data, it is necessary to consider the procedure used, as will be noted below. Those using the more sensitive cyanogen bromide reaction rarely found an absence of nicotinic acid in the urine. Harris and Raymond (36) Kühnau (15) and Rosenblum and Jolliffe (38), on the basis of a small number of observations, considered that the difference in the urinary nicotinic acid in normal and deficient subjects was significant. * Swaminathan (35) reported a marked overlapping of the values for the two groups, although he did find a decreased average secretion in the deficient group. As has been noted, the chemical methods are not specific for nicotinic acid and its derivatives. Much of the difference in the urinary " nicotinic acid" of the normal and deficient groups may have been due to smoking by the former group.

Attention to the different procedures used by those employing the cyanogen bromide and aromatic amine reagents indicates that the nicotinic acid compounds included in the reported " nicotinic acid" values differ in the various studies. This will depend upon the type of hydrolysis used, the method for decolorization and evaluation of residual color, and the aromatic amine employed. Bandier (34) and Harris and Raymond "(36) must have measured all of the nicotinic acid, nicotinamide and nicotinuric acid, and possibly a slight amount of trigonelline. Swaminathan's (35) values included, in addition, an appreciable fraction of the trigonelline. Ritsert's procedure (14) should measure the nicotinic acid, its amide, about two-thirds of the nicotinuric acid (because of the color which it, unhydrolyzed, produces with the 
reagents used (28)) and no trigonelline. The procedure used by Porjé (37), involving no preliminary hydrolysis, should measure any nicotinic acid present, about one-half of the nicotinamide, two-thirds of the nicotinuric acid (by direct reaction with the reagents) and no trigonelline. Rosenblum and Jolliffe's values (38), because of the slight preliminary hydrolysis and the aromatic amide used, presumably include 142 per cent of the nicotinamide and 42 per cent of the nicotinuric acid (values representing the intensities of color produced by these unhydrolyzed molecules with the aromatic amine used relative to those produced by nicotinic acid).

In addition to the differences in what constituted the urinary " nicotinic acid" values, as indicated above, there are other possible discrepancies inherent in the methods listed in Table II. When the test solution is analyzed without preliminary decolorization $(36,37,38)$, the increment of color produced constitutes a small fraction of the total color measured. The use of direct charcoal decolorization $(5,35)$ permits loss of nicotinic acid by adsorption (39). As noted above, benzene extraction $(14,15)$ is unreliable because of the limited solubility of nicotinic acid in benzene (21). In the blank test for evaluating residual color, as used by Bandier (34) and by Rosenblum and Jolliffe (38), nicotinic acid reacts directly with cyanogen bromide to give some of the test color even in the absence of the aromatic amine (39). To include in the blank the color developed by the addition of aniline to the hydrolysate has also been shown to be erroneous, since it is due to a reaction of aniline with other substances which does not occur in the presence of cyanogen bromide (40).

Fraser, Topping and Sebrell (41), using a bacterial growth method with Shigella paradysenteriae, reported a decrease in the urinary excretion of nicotinic acid (or its related compounds) in dogs with blacktongue. In a subsequent paper (25) from the same laboratory, using the Haemophilus parainfluenzae, no such difference in the urinary excretion values was reported. Harris and Raymond (36) observed a decrease in the urinary excretion of nicotinic acid (chemically determined) in guinea pigs on an inadequate diet only after marked weight losses and within a week before death. In the case of the sheep, Winegar, Pearson and Schmidt (42) were unable to find any decreases in nicotinic acid excretion.

\section{EXPERIMENTAL}

We have studied the possibility of the chemical diagnosis of nicotinic acid deficiency by simple analyses of urine and blood and by a variety of "saturation tests."

An application of the cyanogen bromide and aniline reagents, which we have described $(39,40,28)$ was used for the determination of nicotinic acid and its compounds. It is designed to avoid errors, which are due to inadequate extraction or to adsorption, by direct hydrolysis of the test substance followed by preferential charcoal adsorption for the decolorization of the hydrolysate. By this method the blood nicotinic acid values are higher than those reported by other chemical methods and fall within the range of the values obtained by bacterial growth or enzyme fermentation methods (Table I). Nicotinamide and coenzyme I added to blood have been found to be completely hydrolyzed and recovered as free nicotinic acid (4).

Studies of the blood and plasma nicotinic acid content. The whole blood nicotinic acid values of 17 patients before treatment are presented in Table III. In some of them, the nicotinic acid content of the plasma was also determined. The figures obtained fall well within the range of those found in $\mathbf{4 0}$ normal subjects.

TABLE III

Comparison of the blood nicotinic acid values of normal subjects and of nicotinic-acid-deficient patients before treatment

\begin{tabular}{|c|c|c|c|c|}
\hline $\begin{array}{c}\text { Case } \\
\text { number }\end{array}$ & Sex & $\begin{array}{l}\text { Degree of } \\
\text { deficiency }\end{array}$ & $\begin{array}{l}\text { Whole blood } \\
\text { values }\end{array}$ & $\underset{\text { value }}{\text { Plasma }}$ \\
\hline $\begin{array}{r}1 \\
2 \\
4 \\
5 \\
8 \\
9 \\
10\end{array}$ & $\begin{array}{l}F \\
F \\
F \\
F \\
F \\
F \\
M\end{array}$ & $\begin{array}{l}\text { Marked } \\
\text { Marked } \\
\text { Marked } \\
\text { Marked } \\
\text { Marked } \\
\text { Marked } \\
\text { Marked }\end{array}$ & $\begin{array}{c}\text { mgm. per cent } \\
0.66 \\
0.49 \\
0.94^{*} \\
0.77 \\
0.81 \\
0.61 \\
0.69\end{array}$ & $\begin{array}{c}\text { mgm. per cent } \\
\\
0.15 \\
0.14 \\
0.26\end{array}$ \\
\hline $\begin{array}{l}11 \\
12 \\
13 \\
14 \\
15\end{array}$ & $\begin{array}{l}\mathbf{F} \\
\mathbf{F} \\
\mathbf{M} \\
\mathbf{F}\end{array}$ & $\begin{array}{l}\text { Moderate } \\
\text { Moderate } \\
\text { Moderate } \\
\text { Moderate } \\
\text { Moderate }\end{array}$ & $\begin{array}{l}0.55 \\
0.64 \\
0.75 \\
0.67 \\
1.00\end{array}$ & 0.00 \\
\hline $\begin{array}{l}17 \\
18 \\
19 \\
21 \\
22\end{array}$ & $\begin{array}{l}\mathbf{F} \\
\mathbf{F} \\
\mathbf{M} \\
\mathbf{M}\end{array}$ & $\begin{array}{l}\text { Suboptimal } \\
\text { Suboptimal } \\
\text { Suboptimal } \\
\text { Suboptimal } \\
\text { Suboptimal }\end{array}$ & $\begin{array}{l}0.87 \\
0.64 \\
0.57 \\
0.71 \\
0.56\end{array}$ & $\begin{array}{l}0.13 \\
0.20\end{array}$ \\
\hline \multicolumn{4}{|c|}{$\begin{array}{cc}\text { Normal controls (40 subjects) } \dagger & \\
\text { Average } & 0.67 \\
\text { Range } & 0.52-0.83\end{array}$} & $\begin{array}{c}\text { (10 subjects) } \\
0.15 \\
0.05-0.24\end{array}$ \\
\hline
\end{tabular}

* This patient had an hematocrit of 52 per cent.

$\uparrow$ The data on the normal blood and plasma nicotinic acid values are presented elsewhere (4). 


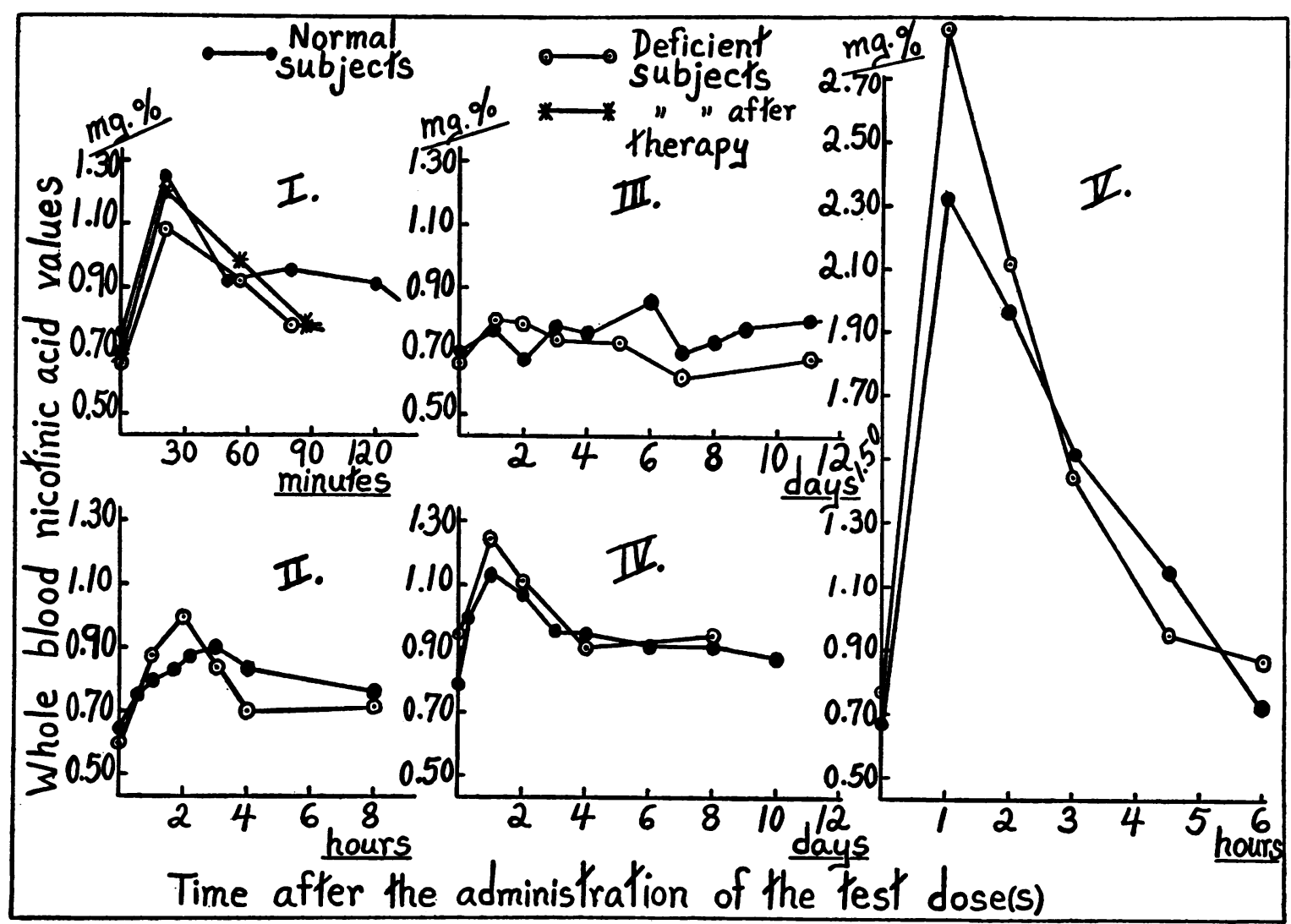

Fig. 2. Typical Blood Nicotinic Acid and Nicotinamide Tolerance Curves Obtained With Normal and Nicotinic-ACID-DEFICIENT SUBjeCtS

Graph I. Following the intravenous administration of nicotinamide, $5 \mathrm{mgm}$. per kilogram of body weight.

Graph II. Following the oral postprandial administration of $500 \mathrm{mgm}$. of nicotinic acid.

Graph III. During the postprandial ingestion of $200 \mathrm{mgm}$. of nicotinamide, three times daily. Each blood sample was taken at least 12 hours after the last dose.

Graph IV. Following the oral administration of nine $200 \mathrm{mgm}$. doses of nicotinic acid, one every 2 hours. (The values are plotted in days after the ingestion of the first of the test doses.)

Graph $V$. Following the intramuscular administration of nicotinamide, $500 \mathrm{mgm}$. per square meter of surface area.

A large number of "tolerance curves" of blood nicotinic acid values were obtained following the administration of nicotinic acid or nicotinamide to normal and deficient subjects. Since the data are voluminous and the results are negative, only the curves obtained with one normal subject and with one definitely deficient patient are presented for each of five different procedures (Figure 2). All the tests have been confirmed by similar studies with other normal and deficient subjects.

In Graph I of the figure are plotted the serial blood values obtained following the intravenous administration of nicotinamide, $5 \mathrm{mgm}$. per kilogram of body weight (equivalent to about nine times the total quantity, free and combined, of nicotinic acid in the blood). In no case of nicotinic acid deficiency was there any significant difference from the normal in the rate of removal of the amide from the blood stream. Even when the test was repeated with the same patient, shortly after 2 weeks of intensive nicotinamide therapy, no appreciable change in the tolerance curve was noted. The relatively small increase in the blood nicotinic acid and the prompt return to the basal level, which was noted in every case, could not be explained by rapid excretion of the compound. Only 10 per cent of the test dose was found in the urine.

The serial blood values obtained following the oral postprandial administration of $500 \mathrm{mgm}$. of nicotinic acid (Graph II) likewise showed no significant difference between the normal and deficient subjects. In this type of test there is a slower increase in the blood nicotinic acid concentration, the maximum being attained from 2 to 3 hours after the test dose is taken. The maximal values, however, are much smaller than those recorded in Graph I following intravenous administration. 
H. FIELD, JR., D. MELNICK, W. D. ROBINSON, AND C. F. WILKINSON, JR.

In Graph III are presented typical blood values obtained during the postprandial administration of $200 \mathrm{mgm}$. of nicotinamide three times daily over a period of 11 days. Each blood sample was taken at least 12 hours after the last dose. No significant differences were observed between the blood values obtained with the normal and deficient subjects. In no case were there significant variations from the initial basal blood values.

It was thought that possibly in the above tests the increases in the blood values were not sufficiently large or prolonged to allow differences in the rate of removal of nicotinic acid (or amide) from the blood to be noted. In Graph IV the serial blood values following the oral administration of nine $200 \mathrm{mgm}$. doses of nicotinic acid, one every 2 hours, are plotted. In these tests the elevated blood values persisted over an appreciable period of time (more than 7 days) but, again, differences between the responses of the normal and deficient subjects were not apparent.

In Graph V are presented representative data following the intramuscular administration of nicotinamide, 500 mgm. per square meter of surface area. In these tests, markedly elevated blood values were obtained and these persisted for a considerable period of time (more than 3 hours). However, no differences were observed between the blood values obtained with normal and deficient subjects.

Extensive studies involving serial plasma nicotinic acid determinations were not carried out. Preliminary investigations (4) had shown that the plasma values return to the basal level even more promptly than those for whole blood.

Studies of the urinary excretion of nicotinic acid and its derivatives. In Table IV are presented the results of analyses of 24-hour urine specimens from normal subjects and from patients with severe dietary deficiency. Four of the patients had fully developed "classic" pellagra. Case 3 had alcoholic neuritis with a mildly reddened tongue and no significant skin changes. The other

TABLE IV

Urinary excretion during abstinence from coffee, tobacco, tea and chocolate

\begin{tabular}{|c|c|c|c|c|c|}
\hline \multicolumn{3}{|c|}{ Normal subjects } & \multicolumn{3}{|c|}{ Deficient subjects } \\
\hline Case & $\begin{array}{c}\text { Nicotin- } \\
\text { amide }\end{array}$ & $\begin{array}{l}\text { Trigo- } \\
\text { nelline }\end{array}$ & Case & $\begin{array}{c}\text { Nicotin- } \\
\text { a mide }\end{array}$ & $\begin{array}{l}\text { Trigo- } \\
\text { nelline }\end{array}$ \\
\hline \multirow{8}{*}{$\begin{array}{l}\text { M. E. B. } \\
\text { M. E. B. } \\
\text { M. E. B. } \\
\text { M. E. B. } \\
\text { H. G. W. }\end{array}$} & $\begin{array}{l}\text { mgm. per } \\
24 \text { hours }\end{array}$ & $\begin{array}{l}\text { mgm. per } \\
24 \text { hours }\end{array}$ & & $\begin{array}{l}\text { mgm. per } \\
24 \text { hours }\end{array}$ & $\begin{array}{l}\text { mgm. per } \\
24 \text { hours }\end{array}$ \\
\hline & 3.4 & 12.0 & 1 & 1.3 & 3.9 \\
\hline & 4.1 & 13.8 & 2 & 3.6 & 1.5 \\
\hline & 5.5 & 12.3 & 2 & 3.3 & 3.3 \\
\hline & 4.1 & 9.0 & 3 & 4.2 & 7.5 \\
\hline & 3.1 & 10.2 & 4 & 3.6 & 1.2 \\
\hline & 3.5 & 16.8 & 5 & 1.7 & 3.0 \\
\hline & 3.6 & 15.8 & 6 & 2.8 & 3.3 \\
\hline \multicolumn{3}{|c|}{$\begin{array}{c}15 \text { other specimens from } \\
8 \text { subjects }\end{array}$} & 7 & 1.2 & 0.9 \\
\hline & $|2.8-6.2|$ & $6.9-42.0$ & 7 & 2.6 & 3.3 \\
\hline Average & 3.8 & 19.5 & Average & 2.7 & 3.1 \\
\hline
\end{tabular}

2 patients had pyloric or intestinal obstruction and had eaten very little for a considerable time but had only minor skin changes.

During the time of collection of the specimens, and usually for one or more days before, the subjects abstained from the use of tobacco, coffee, tea and chocolate. Preliminary observations have indicated that the latter two substances affect the results very little. The use of coffee and tobacco, as noted above, causes large increases in the trigonelline and, in some individuals, in the apparent nicotinic acid excretion; these increases are unrelated to the vitamin metabolism. The avoidance of them is a minimal requirement for a basal regime which will permit chemical analyses of urine by present methods to have any significance in relation to nicotinic acid nutrition.

It will be seen that the apparent nicotinic acid excretion of the deficient subjects tended to be less than that of the normal subjects, averaging $2.7 \mathrm{mgm}$., against 3.8 $\mathrm{mgm}$. per 24 hours. There were, however, several instances of overlapping of values between the two groups. It is quite possible that this overlapping was due to the excretion of other ingested pyridine compounds and might not occur with a more specific method of analysis.

The differences between the trigonelline excretions of the deficient and the normal subjects were must greater; an average value of $3.1 \mathrm{mgm}$. per 24 hours for the deficient group compared with $19.5 \mathrm{mgm}$. per 24 hours for the normal group. They were also much more consistent. The one patient whose trigonelline excretion approximated the lowest value obtained in any normal subject, and who had alcoholic neuritis, was a non-smoker. The analysis was done so long after the collection of the specimen that it was impossible to determine if the coffee had been omitted.

\section{DISCUSSION}

We had found that, in a dog, the blood nicotinic acid remained elevated for many hours after the intravenous injection of a sufficiently large dose of nicotinic acid. The doses required were large-10 mgm. per kilo. Giving comparable parenteral doses of nicotinic acid to humans was not feasible but we had found that such parenteral doses of nicotinamide produced no unpleasant symptoms in ourselves other than some local pain, when given intramuscularly. Because it had been demonstrated that the tissues of experimentally deficient animals had a decreased content of nicotinic acid-containing enzymes, it was thought possible that nicotinic acid and nicontinamide would be removed from the blood of deficient subjects faster than from that of normal subjects. Such does not appear to happen. We have found no indication that the blood nicotinic acid content, 
either under basal conditions or after any type of dosage, is a measure of nicotinic acid nutrition.

This is unfortunate because the present chemical methods for determination of nicotinic acid are not specific. Other pyridine compounds present in vegetable materials give reactions similar to those of nicotinic acid and the methylated form, trigonelline, in which the greater part of nicotinic acid is excreted in the urine. It is possible that a more specific method would show more distinctive differences in the urinary excretion of nicotinamide.

In order to make determinations of trigonelline excretion significant as a measure of nutrition, it is necessary to have subjects on a basal regime eliminating at least the major sources of trigonelline of non-vitamin origin-coffee and tobacco. What further standardization of the basal regime is desirable remains to be determined. It may be that part of the decrease in the trigonelline excretion of the deficient subjects was due to a lesser intake of preformed trigonelline in a smaller intake of all foods. It appears that, with a sufficiently standardized basal regime and with a satisfactorily quantitative method of recovery of trigonelline, its excretion in the urine may be a measure of nicotinic acid nutrition.

\section{SUM MARY}

1. A review of the literature has shown no agreement as to the value of determination of the nicotinic acid compounds in urine or blood as a measure of nicotinic acid nutrition.

2. The data of the earlier reports have been re-assessed, in the light of more recent knowledge, to indicate what compounds were included in the reported " nicotinic acid" values, and the validity of methods has been discussed.

3. In the present study, no differences were observed in the basal blood or plasma nicotinic acid content of normal and deficient subjects.

4. Five different types of blood nicotinic acid or nicotinamide tolerance curves showed no difference between normal and deficient subjects.

5. With the procedures used in this study there was an average, but not a constant, decrease in the urinary excretion of substances reacting like nicotinamide by deficient subjects.

6. There was a more marked and a more consistent decrease in the urinary excretion of tri- gonelline in the deficient subjects. With a sufficiently standardized basal regime and with a satisfactorily quantitative method of recovery of trigonelline, the urinary excretion of trigonelline may be a measure of nicotinic acid nutrition.

\section{BIBLIOGRAPHY}

1. Elvehjem, C. A., and others, Relation of nicotinic acid and nicotinic acid amide to canine blacktongue, J. Am. Chem. Soc., 1937, 59, 1767.

2. König, W., Utber eine neue, vom Pyridin derivierende Klasse von Farbstoffen. J. prakt. Chem., 1904, 69, 105.

3. Elvehjem, C. A., personal communication.

4. Melnick, D., Robinson, W. D., and Field, H., Jr., Factors affecting the concentration and distribution of nicotinic acid in the blood. J. Bol. Chem., 1940, 136, 157.

5. Vilter, S. P., Spies, T. D., and Mathews, A. P., A method for the determination of nicotinic acid, nicotinamide and possibly other pyridine-like substances in human urine. J. Biol. Chem., 1938, 125, 85.

6. Vilter, S. P., Koch, M. B., and Spies, T. D., Coenzymes I and II in human blood. J. Lab. and Clin. Med., 1940, 26, 31.

7. Querido, A., Lwoff, A., and Lataste, Le Dosage de la nicotinamide dans le sang. Compt. rend. Soc. biol., 1939, 130, 1580.

8. Ballif, L., and others, La nicotinamidémie chez les pellagreaux. Compt. rend. Soc. de biol., 1939, 131, 903.

9. Kohn, H. I., Bernheim, F., and Felsoranyi, A. V., The blood $V$-factor (coenzyme) level in normal and pathological subjects. J. Clin. Invest., 1939, 18, 585.

10. von Euler, H., and Schlenk, F., Nicotinsäureamid und Co-zymase im Blut. Klin. Wchnschr., 1939, 18, 1109.

11. Axelrod, A. E., and Elvehjem, C. A., The determination of coenzyme I in animal tissues. J. Biol. Chem., 1939, 131, 77.

12. Axelrod, A. E., Gordon, E. S., and Elvehjem, C. A., The relationship of dietary intake of nicotinic acid to the coenzyme I content of the blood. Am. J. M. Sc., 1940, 199, 697.

13. Swaminathan, M., A chemical method for the estimation of nicotinic acid in biological materials. Indian J. M. Research, 1938, 26, 427.

14. Ritsert, K., Zur quantitativen Nicotinsäure- 'und Nicotinsäureamid-Bestimmung im Harn, in Geweben und im Blut. Klin. Wchnschr., 1939, 18, 934.

15. Kühnau, W. W., Uber das Verhalten der Nicotinsäuere in den Körpersäften bei Pellagra und bei Gesunden. Klin. Wchnschr., 1939, 18, 1333.

16. Villela, G. G., Dosagem do ácido nicotinico (Vitamina P-P) no sangue. Hospital, Rio de Janeiro, 1940, $17,431$. 
17. Kohn, H. I., The concentration of coenzyme-like substances in blood following the administration of nicotinic acid to normal individuals and to pellagrins. Biochem. J., 1938, 32, 2075.

18. Sinclair, H. M., The estimation of vitamin $B_{1}$ in blood. II. A further modification of Meikeljohn's method. Biochem. J., 1939, 33, 2027.

19. von Myrback, K., Co-zymase. Ergebn. d. Enzymforsch., 1933, 2, 139.

20. Hahn, A., Gerstenberger, H., and Mehler, E., Die Herstellung von Kozymasepräparaten zu Fermentversuchen. Ztschr. Biol., 1938-39, 99, 457.

21. Waisman, H. A., and Elvehjem, C. A., The chemical estimation of nicotinic acid and vitamin $B_{6}$. Division of Biological Chemistry, American Chemical Society, Detroit, Sept., 1940. Indust. and Engin. Chem., Analyt. Ed., 1941, 13, 221.

22. Pearson, P. B., The nicotinic acid content of the blood of Mammalia. J. Biol. Chem., 1939, 129, 491.

23. Kohn, H. I., Klein, J. R., and Dann, W. J., The $V$ factor content and oxygen consumption of tissues of the normal and blacktongue dog. Biochem. J., 1939, 33, 1432.

24. Axelrod, A. E., Madden, R. J., and Elvehjem, C. A., The effect of nicotinic acid deficiency upon the coenzyme I content of animal tissues. J. Biol. Chem., 1939, 131, 85.

25. Pittman, M., and Fraser, H. F., The determination of $V$-factor in the urine and tissues of normal dogs and of dogs with blacktongue by the use of Haemophilus parainfluenzae. U. S. Pub. Health Repts., 1940, 55, 915.

26. Winegar, A. H., and Pearson, P. B., The requirements of herbivora for nicotinic acid and grassjuice factor. Proc. Am. Soc. Animal Production, 1939, 32, 384.

27. Melnick, D., Robinson, W. D., and Field, H., Jr., Urinary excretion of nicotinic acid and its derivatives by normal individuals. J. Biol. Chem., 1940, 136, 145.

28. Melnick, D., Robinson, W. D., and Field, H., Jr., Influence of the excretion of other pyridine compounds upon the interpretation of the urinary nicotinic acid values. J. Biol. Chem., 1940, 136, 131.
29. Perlzweig, W. A., Levy, E. S., Sarett, H. P., Nicotinic acid derivatives in human urine and their determination. J. Biol. Chem., 1940, 136, 729.

30. Barger, G., The simpler natural bases. Longmans, London, 1914.

31. Linneweh, W., and Reinwein, H., Uber das Vorkommen von Pyridin-derivaten in normalen Harn. Ztschr. physiol. Chem., 1932, 207, 48.

32. Heiduschka, A., and Brückner, R., Úber das Vorkommen von Trigonellin in Guatamala-Kaffee. J. Prakt. Chem., 1931, 130, 11.

33. Woolley, D. W., and others, Anti-blacktongue activity of various pyridine derivatives. J. Biol. Chem., 1938, 124, 715.

34. Bandier, E., Quantitative estimation of nicotinic acid in urine. Biochem. J., 1939, 33, 1787.

35. Swaminathan, M., The urinary excretion of nicotinic acid. Indian J. M. Research, 1939, 27, 417.

36. Harris, L. J., and Raymond, W. D., Assessment of the level of nutrition. A method for the estimation of nicotinic acid in urine. Biochem. J., 1939, 33, 2037.

37. Porjé, I. G., En metod att bestamma nikotinsyra (pyridinderivat) i urin. Nord. Med., 1939, 2, 1108.

38. Rosenblum, L. A., and Jolliffe, N., Application to urine of Bandier and Hald's method for the determination of nicotinic acid. J. Biol. Chem., 1940, 134, 137.

39. Melnick, D., and Field, H., Jr., Determination of nicotinic acid in biological material by means of photoelectric colorimetry. J. Biol. Chem., 1940, 134, 1.

40. Melnick, D., and Field, H., Jr., Chemical determination of nicotinic acid: inhibitory effect of cyanogen bromide upon the aniline side reactions. J. Biol. Chem., 1940, 135, 53.

41. Fraser, H. F., Topping, N. H., and Sebrell, W. H., The assay of urine in canine blacktongue by the use of Shigella paradysenteriae (Sonne). U. S. Pub. Health Rep., 1938, 53, 1836.

42. Winegar, A. H., Pearson, P. B., and Schmidt, -, Synthesis of nicotinic acid in the body of sheep. Science, 1940, 91, 508. 